\title{
A Review on Abiotic Stress Caused by Industrial Effluents on Seed Quality
}

\author{
B. Venudevan ${ }^{1^{*}}$, P. Srimathi ${ }^{2}$ and M. Ameer Junaithal Begum ${ }^{1}$ \\ ${ }^{1}$ Department of Seed Science and Technology, Tamil Nadu Agricultural University, Coimbatore, India. \\ ${ }^{2}$ Seed Centre, Tamil Nadu Agricultural University, Coimbatore, India.
}

\begin{abstract}
Authors' contributions
This work was carried out in collaboration among all authors. Author BV managed the literature searches and wrote the first draft of the manuscript. The remaining authors $P S$ and MAJB was proof read and corrected the draft. All authors read and approved the final manuscript.
\end{abstract}

Article Information

DOI: $10.9734 / A R R B / 2019 /$ v31i230046

Editor(s):

(1) Dr. George Perry, Dean and Professor of Biology, University of Texas at San Antonio,

USA.

Reviewers:

(1) Diego Ariel Meloni, National University of Santiago del Estero, Argentina.

(2) Zainab Abubakar, University of Aberdeen, UK.

Complete Peer review History: http://www.sdiarticle3.com/review-history/11427

Review Article

Received 15 April 2014

Accepted 08 July 2014

Published 26 March 2019

\section{ABSTRACT}

India is one of the top ten industrialized countries of global importance. But industries release waste products, which exert negative influences by causing toxicity to biotic organisms and environment. Liquid wastes of industries termed as effluents are characterized with possession of organic and inorganic compounds that evolve with varying levels of toxicity based on the type of industry and its bi-product. Recycling of treated effluent serves as an alternative to tie over water scarcity in sustainable agriculture. On the other hand, dilutions of industrial effluents serves as growth stimulants at an optimal concentration and influences the seed and seedling quality characters and aids in improving the productivity of crops. The safe levels of dilutions expressing the seed invigourative effect are reviewed hereunder, which could serve as a solution for disposal of effluent in agriculture in an effective manner.

Keywords: Industrialization; effluents; toxicity; dilution; seed invigoration.

${ }^{*}$ Corresponding author: E-mail: Venudevan005@gmail.com; 


\section{INTRODUCTION}

With increasing global population, the gap between the supply and demand for water is widening and is reaching alarming levels in some parts of the world and is posing threat to human existence. Scientists around the globe are working on new ways of conserving water. India is one among the first ten industrialized countries of global importance. Though industrialization is the entry point for national development, industries such as metal cleaning, paper and pulp, dairy, tanneries, textile and dye, sugar mills, distilleries, sago and starch, fertilizers, plating baths, electroplating and paint not only produce the products but also release wastes, which exert negative influences on man and environment causing toxicity to plants and other forms of biotics organisms.

The State Board, based upon the large database in terms of effluents and emissions generated over the years of its existence, has categorized industries as Red (highly polluting industries), Orange (moderately polluting industries) and Green (marginally polluting units) (dpcc.delhigovt.nic.in) [1] distilleries, paper and pulp mills, dairy industries, sugar mills, tanneries, textile, fertilizers industries and dye, brewery industries, sago and starch industries etc are highly polluting categorized industries (CPCB), while the sheet glass and photo framing, automobile servicing and repairs stations, hotels and restaurants, instant tea/coffee, coffee processing, non-alcoholic beverages (soft drinks), fragrances and industrial perfumes, fish processing, organic nutrients, surgical and medical products, laboratory-wares, stone crushers, tyres and tubes vulcanization, retreading molding are classified as orange category. The industries coming under green category are rice mullors, mineralized water, dal mills, bakery products, biscuits, confectionery, groundnut decorticating (dry), masala grinding, chilling plants and cold storages, ice cream or ice-making, tailoring, garment making, handloom weaving, gold and silver thread zari work, gold and silver smithy and manufacturing of musical instruments and sports goods.

Recycling of industrial waste water and urban wastewater for irrigation and other purposes [2] are attracting the researchers for obtaining beneficial and economic results. Waste water of industries creates potential hazards for our environment because of the introduction of various contaminants such as heavy metals into soil and water resources in addition to the consumption of higher quantum of water for basic functioning. Presence of pollutants in effluent is a common environmental hazard since the toxic metal ions dissolved can ultimately reach the top of the food chain and becomes a risk factor for human beings. The effluents are not only a rich source of organic matter but also contain heavy metals like $\mathrm{Fe}, \mathrm{Mn}, \mathrm{Cu}, \mathrm{Zn}, \mathrm{Pb}, \mathrm{Cr}$ and Ni. Continuous use of such effluents for crop production could result in accumulation of these metals in the soil as well as in plants, in concentrations that may become phytotoxic. Accumulation of heavy metals over prolonged time becomes hazardous to animals and human health after entering in their body systems through food chain. Heavy metal pollution of agricultural soils is one of the most severe ecological problems faced worldwide. The environment is under increasing pressure from solid and liquid waste emanating from the leather industry. The byproducts of the leather manufacturing process cause significant pollution unless treated in someway prior to discharge. Tanning industrial wastes are a serious threat when they pollute streams, fresh water bodies and land. The wastes from this industry rank among the most polluting of all industrial wastes. Chemicals such as sodium chloride, sodium sulfite, lime and chromium used at different stages of tanning process are present in the discharged effluent. When used for irrigation, the effluent containing chromium in non-permissible limits can prove to be phytotoxic. Which exists in two oxidation states, trivalent (CrIII) and hexavalent ( $\mathrm{CrVI})$. Both the forms are toxic to the plants and inhibit germination, reduce growth, generate oxidative stress, decrease protein content, inhibit photosynthesis and alter enzyme activities in the exposed plants. Reactive oxygen species (ROS) are produced in plants in response to the damaging effects of environmental stresses and plants have evolved a variety of antioxidant defense mechanisms in response to stress. Thus, wastewater can be considered as both a resource and a problem. Wastewater and its nutrient content can be used extensively for irrigation and other ecosystem services. Its reuse can deliver positive benefits to the farming community by proper management practices Hari et al. [3].

\subsection{Problem and Prospects Liquid Industrial Waste}

Ground water is the important source of potable water utilized for the agricultural irrigation and 
industrial production. It is experiencing an increasing threat of pollution coming from urbanization and industrial development [4]. These pollutants find their way to aquatic ecosystem such as rivers, ponds and lakes which pose a risk to the health of human and ecosystem [5]. The global water pollution due to the increase in number of industries is a serious problem faced by the modern world. Soil serves as the most important component as the ultimate sink for the pollutants discharged into the environment [6]. Gowd et al. [7] also ensured the entry of the organic and inorganic contaminants from the disposal of industrial effluents contaminate the soils with heavy metals or micronutrients in phytotoxic concentrations and generates adverse effects not only on plants but also poses risks to human health [8].

Almost all industries discharge water containing wastes in one stage or another during their manufacturing process, which are not the same in every case. As a result, the presence of pollutants in water alters different physico chemical parameters from their normal prescribed levels. Annual waste water discharge and consumption of industrial sectors is explained by www.downtoearth.org.in [9] as in Table 1.

The increase in requirement of fresh water for industrial use also alarmed to rose from $30 \mathrm{BCM}$ (Billion Cubic Meters) to 120 BCM by 2025 AD. (www.cseindia.org) [10] Negative impacts on water quality include increase in turbidity, colour, nutrient load and addition of toxic and persistent compounds [11].

\subsection{Effect of Industrial Effluent on Seed Quality}

In line with views of Hari et al. [3] effluents are much harmful for expression of physiological seed quality characters. At 100 per cent concentration, they reduce the quality to the maximum level and decayed the seed due to imbibitions of toxic material at lethal dose that leads to death of seed either on sowing or at external treatment. Rajannan et al. [12] also reported that Seed germination of Oryza sativa was inhibited by 25 and $50 \%$ effluent and fully dormant by 75 and $100 \%$ effluent. Researchers of various crops for the past three decades tracing the influence of pollution [2,12-41], opined that the effluents exert optimum, supra and sub optimal dose for expression of results on seed germination and seedling growth characters.

\subsection{Causes for Negative Influence of Direct Effluents}

Rajaram and Janardhanam, [42] revealed that processed distillery effluents were rich in inorganic constituents like ammoniacal nitrogen and traces of heavy metals and these markedly suppressed the germination per cent and early growth of the seedling as the concentration of the effluent increase. Rout [43] revealed that irrigation with paper factory effluent in experimental plantations of 13 tree species, found to reduce the germination, shoot growth, root growth, chlorophyll content, protein content, DNA, RNA, free amino acids and soluble sugar of plants The content of chlorophyll ' $a$ ' and ' $b$ ' decreased with increase in the concentration of the effluent. Mishra and Bera [44] showed that olive Mill waste water had phototoxic influence on wheat due to the polyphenols and other unidentified material. Selvakumar [20] also revealed that at higher concentrations of tannery effluents, due to the presence of organic compounds, acids, alkalies, suspended solids and heavy metal, growth of the new seedlings were inhibited. Vidhya [27] expressed the causes for inhibited growth of seedlings as high

Table 1. Annual waste water discharge and consumption of industrial sector

\begin{tabular}{lll}
\hline Industrial sector & $\begin{array}{l}\text { Annual wastewater water discharge } \\
\text { (million cubic meters) }\end{array}$ & $\begin{array}{l}\text { Annual consumption } \\
\text { (million cubic meters) }\end{array}$ \\
\hline Thermal power plants & 27000.9 & 35157.4 \\
Engineering & 1551.3 & 2019.9 \\
Pulp and paper & 695.7 & 905.8 \\
Textiles & 637.3 & 829.8 \\
Steel & 396.8 & 516.6 \\
Sugar & 149.7 & 194.9 \\
Fertiliser & 56.4 & 73.5 \\
Others & 241.3 & 314.2 \\
Total & $\mathbf{3 0 7 2 9 . 2}$ & $\mathbf{4 0 0 1 2 . 0}$ \\
\hline
\end{tabular}


respiration which is utilized in building new protoplasm, which results in growth of new embryo where, due to enhanced salinity and conductivity of solutes, imbibition decreases and the oxygen for germination is reduced. Rani and Alikhan, [45] noticed that the percentage germination and seedling energy of rice and wheat reduced significantly with a raise in spent wash concentration.

Singh et al. [31] also reported that absorption of higher dissolved solids by the seed affected the germination on usage of tannery effluent. Madhumita et al. [32] also reported that under 100 per cent concentrations paper mill effluent had inhibitory effect and alter the salt concentration of soil and build up salinity in soils that resulted in disturbance of seed water interaction necessary for triggering the enzyme system and nutrients concentration was too high to become toxic, resulting in restricted seedling growth. On dilution due to presence of nutrients like nitrogen, potassium, calcium and magnesium in diluted effluents at optimum concentration promoting growth of the seedlings. Yadav and Meenakshi, [35] to assess the toxicity of effluent on seedling germination, seedling growth, biomass and crop yield of Raphanus sativus var. Pusa Chetki (Raddish) and Hibiscus esculentus versha uphar (Bhendi) and found that the germination per cent decreased with rising effluent concentration.

Mahimairaja [37] expressed that at higher concentrations, germination reduced due to accumulation of excess inorganic salts that distrub osmatic relation of the seed with the water. Accumulation of salts like chloride create water stress induced by high osmotic pressure at high concentration that might reduced germination and inhibit enzyme activity. While, Dhanam [40] opined that germination percentage and seedling growth was inhibited at 100 per cent concentration due to higher osmotic pressure of the effluent at higher concentration of total salts made the imbibition more difficult and retarded germination, while the lower concentration of the effluent had promoted the presence of plant nutrient in the effluent. Baskaran et al. [39] also revealed that at higher concentrations, due to the disturbance of the osmotic relations of the seed and water, the amount of absorbed water had been reduced and retarded seed germination by enhanced salinity and conductivity of the solutes. Furthermore, the germinated seeds also did not have any oxygen due to organic and inorganic chemicals present in the effluent.

Table 2. Positive influence of diluted industrial effluents on seed quality characters

\begin{tabular}{|c|c|c|}
\hline Crop & $\begin{array}{l}\text { Concentration and duration of soaking that } \\
\text { influence seed/crop quality characters }\end{array}$ & Authority \\
\hline \multicolumn{3}{|l|}{ Paper mill effluent } \\
\hline Rice seeds & $\begin{array}{l}\text { Pre soaked in } 2.5 \text { to } 5.0 \text { per cent for } 15 \mathrm{~h} \text { enhanced } \\
\text { the germination }\end{array}$ & Dixit et al. [15] \\
\hline $\begin{array}{l}\text { Maize, Wheat, Ragi, } \\
\text { Groundnut and Cotton }\end{array}$ & $\begin{array}{l}\text { Soaked in } 25 \text { per cent influenced the germination } \\
\text { and vigour index }\end{array}$ & $\begin{array}{l}\text { Kannan and } \\
\text { Oblisami, [16] }\end{array}$ \\
\hline Radish & $\begin{array}{l}10 \text { per cent of effluent influenced the mean root } \\
\text { length, shoot length and secondary roots as } \\
\text { compared with control }\end{array}$ & Srivastava, [2] \\
\hline $\begin{array}{l}\text { Neem, Tamarind and } \\
\text { Pungam }\end{array}$ & $\begin{array}{l}75 \text { per cent of seeds germinated at } 25 \text { and } 50 \text { per } \\
\text { cent concentrations. }\end{array}$ & $\begin{array}{l}\text { Gomathi and } \\
\text { Oblisamy, [17] }\end{array}$ \\
\hline Rice & $\begin{array}{l}25 \text { per cent recorded higher seed germination and } \\
\text { seedling quality }\end{array}$ & $\begin{array}{l}\text { Udayasoorian et } \\
\text { al., [21] }\end{array}$ \\
\hline Petunia & $\begin{array}{l}\text { Seed fortification with } 5 \text { per cent dilution recorded } \\
\text { the highest germination of } 90 \text { per cent. }\end{array}$ & Natarajan, [46] \\
\hline Rice PB-1 & $\begin{array}{l}25 \text { per cent effluent dilution enhanced seed } \\
\text { germination and vigour }\end{array}$ & $\begin{array}{l}\text { Madhumita et al., } \\
\text { [32] }\end{array}$ \\
\hline \multicolumn{3}{|l|}{ Dairy effluent } \\
\hline Wheat & $\begin{array}{l}\text { The germination duration was spread over a period } \\
\text { of } 9,7 \text { and } 4 \text { days in pure, diluted effluent and water } \\
\text { respectively. }\end{array}$ & $\begin{array}{l}\text { Goutam and } \\
\text { Bishnoi, [47] }\end{array}$ \\
\hline Barley and Rice & $\begin{array}{l}\text { The germination per cent was maximum at } 25 \text { per } \\
\text { cent dilution. }\end{array}$ & Goutam et al. [48] \\
\hline
\end{tabular}




\begin{tabular}{|c|c|c|}
\hline Crop & $\begin{array}{l}\text { Concentration and duration of soaking that } \\
\text { influence seed/crop quality characters }\end{array}$ & Authority \\
\hline Paddy & $\begin{array}{l}\text { Seed germination, root length and shoot length } \\
\text { increased at } 25 \text { per cent dilution }\end{array}$ & Dhanam, [40] \\
\hline Lady's finger & $\begin{array}{l}\text { Higher germination percentage recorded at } 25 \text { per } \\
\text { cent dilution }\end{array}$ & Sharma et al. [49] \\
\hline \multicolumn{3}{|l|}{ Sugar mill effluent } \\
\hline Greengram & $\begin{array}{l}\text { At ten per cent dilution of sugar mill effluent recorded } \\
\text { more germination compared to higher concentrations }\end{array}$ & Baskaran et al. [39] \\
\hline Blackgram & $\begin{array}{l}\text { Seeds showed reduction in seed germination } \\
\text { percentage as the effluent dilution increased from } \\
20 \text { to } 100 \text { per cent }\end{array}$ & Kailas et al. [41] \\
\hline \multicolumn{3}{|l|}{ Distillery effluents } \\
\hline Phaseolus radiatus & $\begin{array}{l}\text { The percentage germination and speed of } \\
\text { germination index (SGI) is increased with } \\
\text { corresponding increase in distillery effluent diluted to } \\
\text { five per cent and the growth and biomass of } \\
\text { seedlings and their pigment content up to the dilution } \\
\text { of } 10 \text { per cent. }\end{array}$ & $\begin{array}{l}\text { Sahai and Neelam, } \\
{[14]}\end{array}$ \\
\hline Pisum sativam & $\begin{array}{l}\text { Distillery effluent treatment } 10 \text { per cent enhance the } \\
\text { root growth }\end{array}$ & $\begin{array}{l}\text { Rani and } \\
\text { Shrivastava, [50] }\end{array}$ \\
\hline $\begin{array}{l}\text { White sorghum (APK } \\
\text { 1) and Red sorghum } \\
\text { (Namakkal local). }\end{array}$ & $\begin{array}{l}10 \text { per cent dilution reported more germination and } \\
\text { vigour }\end{array}$ & $\begin{array}{l}\text { Zalawadia and } \\
\text { Raman, [19] }\end{array}$ \\
\hline $\begin{array}{l}\text { Acacia catechu and } \\
\text { Morus alba. }\end{array}$ & $\begin{array}{l}\text { The effluent with lowest dilution ( } 10 \text { per cent) } \\
\text { enhanced vigour and mean daily germination } \\
\text { compared to control. }\end{array}$ & $\begin{array}{l}\text { Pandey and Soni, } \\
\text { [51] }\end{array}$ \\
\hline $\begin{array}{l}\text { Oryza sativa L. cv. } \\
\text { Saka-4 and Pusa } 44\end{array}$ & $\begin{array}{l}25 \text { per cent recorded higher germination and other } \\
\text { quality parameters }\end{array}$ & $\begin{array}{l}\text { Chinnusamy et al. } \\
{[22]}\end{array}$ \\
\hline $\begin{array}{l}\text { Tomato, Chilli, Bottle } \\
\text { gourd, Cucumber and } \\
\text { Onion. }\end{array}$ & 10 per cent dilution recorded higher germination & Ramana et al., [21] \\
\hline $\begin{array}{l}\text { Ragi, Sorghum, } \\
\text { Gingelly, Groundnut } \\
\text { and Green gram }\end{array}$ & $\begin{array}{l}\text { Seed soaking in } 10 \text { or } 20 \text { per cent solution of spent } \\
\text { wash at a seed to solution ratio of } 1: 1 \text { for } 16 \mathrm{~h} \text { in ragi } \\
\text { and sorghum for } 12 \mathrm{~h} \text { in gingelly, six hours in } \\
\text { groundnut and three hours in green gram improved } \\
\text { the germination by } 16,27,28,30 \text { and } 28 \% \\
\text { respectively over the control. }\end{array}$ & $\begin{array}{l}\text { Mahimairaja and } \\
\text { Bolan [52] }\end{array}$ \\
\hline Phaseolus aureus & $\begin{array}{l}\text { Seed germination was found stimulatory effect at } \\
\text { one to five per cent }\end{array}$ & Chandra et al. [53] \\
\hline Sorghum & $\begin{array}{l}2.5 \text { per cent distillery spentwash enhanced the seed } \\
\text { germination }\end{array}$ & Kaushik et al., [30] \\
\hline Zea mays and Rice & $\begin{array}{l}50 \text { per cent distillery effluent enhanced the seed } \\
\text { germination and seedling growth of Zea mays and } \\
\text { Rice }\end{array}$ & Pandey et al. [36] \\
\hline \multicolumn{3}{|l|}{ Spent wash effluent } \\
\hline $\begin{array}{l}\text { Soybean, cowpea, rice } \\
\text { and sorghum }\end{array}$ & $\begin{array}{l}\text { Germination percentage and seedling growth } \\
\text { enhanced at lower dilution of } 10 \text { per cent. }\end{array}$ & $\begin{array}{l}\text { Rajaram and } \\
\text { Janardhanam [42] }\end{array}$ \\
\hline $\begin{array}{l}\text { Sorghum, } \\
\text { Green gram }\end{array}$ & $\begin{array}{l}\text { Soaking with } 25 \text { per cent dilution for } 4 \mathrm{~h} \text { recorded } \\
\text { more germination percentage. }\end{array}$ & Vidhya, [27] \\
\hline Bhendi & $\begin{array}{l}\text { Diluted at higher level (50 times) recorded more } \\
\text { seed quality }\end{array}$ & $\begin{array}{l}\text { Soundarrajan and } \\
\text { Pitchai, [33] }\end{array}$ \\
\hline Rice and wheat & $\begin{array}{l}\text { Five per cent dilution enhanced the overall growth of } \\
\text { seedling compared with control. }\end{array}$ & Singh et al. [31] \\
\hline Sorghum & $\begin{array}{l}6.25 \text { per cent dilution resulted in better growth of the } \\
\text { cultivar. }\end{array}$ & $\begin{array}{l}\text { Garg and Kaushik } \\
{[54]}\end{array}$ \\
\hline
\end{tabular}




\begin{tabular}{|c|c|c|}
\hline Crop & $\begin{array}{l}\text { Concentration and duration of soaking that } \\
\text { influence seed/crop quality characters }\end{array}$ & Authority \\
\hline $\begin{array}{l}\text { Mung bean (Vigna } \\
\text { radiata), }\end{array}$ & $\begin{array}{l}\text { Seeds presoaked for } 6 \mathrm{~h} \text { at a dilution of five per cent } \\
\mathrm{v} / \mathrm{v} \text { resulted in increased percentage of germination, } \\
\text { speed of germination index, vigor index and length of } \\
\text { root and embryonic axis }\end{array}$ & $\begin{array}{l}\text { Kannan and Upreti, } \\
\text { [55] }\end{array}$ \\
\hline $\begin{array}{l}\text { Rice (Oryza sativa) and } \\
\text { wheat (Triticum } \\
\text { aestivum) }\end{array}$ & $\begin{array}{l}\text { Seeds hardened at lower dilution (one per cent for } \\
\text { wheat and one per cent, five per cent for rice) } \\
\text { increased the seed germination, seedling growth, } \\
\text { fresh weight and dry weight of seedlings compared } \\
\text { to higher concentration. }\end{array}$ & Rita et al. [56] \\
\hline $\begin{array}{l}\text { Maize, Sunflower and } \\
\text { Red gram }\end{array}$ & $\begin{array}{l}\text { spent wash at } 5 \text { per cent dilution improved the seed } \\
\text { germination }\end{array}$ & Mahimairaja, [37] \\
\hline Blackgram & $\begin{array}{l}\text { Germination percentage, growth and seedling weight } \\
\text { of seedlings increased at } 10 \text { per cent dilution of } \\
\text { spent wash when compared to other concentrations. }\end{array}$ & Indra \\
\hline Finger and Pearl millet & $\begin{array}{l}2.5 \text { to } 5.0 \text { per cent spent wash recorded higher seed } \\
\text { germination and seedling quality }\end{array}$ & $\begin{array}{l}\text { Kalaiselvi et al., } \\
{[36]}\end{array}$ \\
\hline $\begin{array}{l}\text { Groundnut (Arachis } \\
\text { hypogaea L.) cV. TMV7 }\end{array}$ & $\begin{array}{l}\text { Spent wash three per cent dilution for two hours } \\
\text { improved the germination and vigour potential }\end{array}$ & Chidananda, [58] \\
\hline \multicolumn{3}{|l|}{ Tannery effluent } \\
\hline Neem & $\begin{array}{l}25 \text { per cent recorded higher seed germination, root } \\
\text { length and shoot length. }\end{array}$ & Selvakumar, [20] \\
\hline Wheat & 5 per cent recorded more germination. & Singh et al. [31] \\
\hline \multicolumn{3}{|l|}{ Textile effluents } \\
\hline Wheat & 6.25 per cent improved the seed quality & Aliotta et al. [25] \\
\hline Arachis hypogea & $\begin{array}{l}25 \text { per cent had growth promotive effect better than } \\
\text { control by } 4.7 \text { percent }\end{array}$ & Kumar et al. [59] \\
\hline Groundnut & $\begin{array}{l}\text { Effluent at } 50 \text { per cent observed } 95 \text { per cent } \\
\text { germination in TMV-10 and } 92 \text { per cent in JL-24. }\end{array}$ & $\begin{array}{l}\text { Saravanamoorthy } \\
\text { and Ranjitha } \\
\text { Kumari, [60] }\end{array}$ \\
\hline \multicolumn{3}{|c|}{ Fertilizer factory effluents } \\
\hline Groundnut. & $\begin{array}{l}5 \text { per cent recorded higher seed germination and } \\
\text { seedling quality }\end{array}$ & $\begin{array}{l}\text { Sundaramoorthy et } \\
\text { al. [23] }\end{array}$ \\
\hline $\begin{array}{l}\text { Tomato cv. PED, Pusa } \\
\text { Ruby and Rupal-I. }\end{array}$ & $\begin{array}{l}25 \text { per cent recorded higher seed germination and } \\
\text { seedling quality }\end{array}$ & Sharma et al. [26] \\
\hline \multicolumn{3}{|l|}{ Surgical effluent } \\
\hline $\begin{array}{l}\text { Raphanus sativus var. } \\
\text { Pusa Chetki and } \\
\text { Hibiscus esculentus } \\
\text { versha uphar }\end{array}$ & $\begin{array}{l}\text { The germination per cent was maximum with } 25 \text { per } \\
\text { cent surgical effluent dilution. }\end{array}$ & $\begin{array}{l}\text { Yadav and } \\
\text { Meenakshi, [35] }\end{array}$ \\
\hline
\end{tabular}

Giovacchino et al. [61] revealed that the grain yield and biomass yield of maize was significantly higher due to spent wash application at 25 per cent concentration as it increased the $\mathrm{N}, \mathrm{P}, \mathrm{K}, \mathrm{Ca}, \mathrm{Mg}$ and $\mathrm{Na}$ content in all the parts of the maize crop. Studies also revealed that at low concentrations the seedling vigour and field performance were improved due to the diluted concentration of organic and inorganic salt of the effluent and the benefit also has been prolonged upto productivity. Even on practicing irrigation, these type of dilution before irrigation would help in proper and efficient utilization of waste material as blessing.

\section{MANAGEMENT STRATEGIES FOR INDUSTRIAL EFFLUENT AND ITS AFFECTED AREAS}

\subsection{Selection of Tolerant Crops in the Industrial Effluent Area}

Choice of crop and variety within the crop has been expressed as management practice to get rid of the ill effects of effluents irrespective of its type. Industrial effluents have higher level of salt content and heavy metals hence, selection of salt and heavy metal tolerant crops will ensure better 
germination, growth and yield of crops in affected areas.

Sundaramoorthy et al. [23] also reported VRI 2 as tolerant variety to withstand the illeffects of effluents. Ramana et al. [24], based on the influence of distillery effluent, categorized the tolerant levels of the crops as: cucumber $>$ chilli> onion $>$ bottle gourd $>$ tomato.

\subsection{Dilution of Effluents}

The effluents could be diluted in conjunction with earlier results to tolerable concentration and can be used either for irrigation or for seed soaking to enhance the beneficial effects of effluents.

\subsection{Wastewater Treatment}

There are conventional and non-conventional methods of wastewater treatment which been proven and efficient in treatment of wastewater. But require skilled labour for operation and maintenance of the system.

\subsection{Conventional Methods}

Conventional wastewater treatment methods are activated sludge, trickling filter, rotating biological contactor methods. Trickling filters and Rotating Biological Contactors are temperature sensitive, remove less BOD, and trickling filters cost more to build than activated sludge systems. Activated sludge systems are much more expensive to operate because energy is needed to run pumps and blowers (National Programme on Technology Enhanced Learning (NPTEL).

\subsection{Non-Conventional Methods}

These are low-cost, low-technology, less sophisticated in operation and maintenance biological treatment systems for municipal wastewater. Although these systems are land intensive by comparison with the conventional high-rate biological processes, they are often more effective in removing pathogens and do so reliably and continuously if system is properly designed and not overloaded [62]. Some of the non-conventional methods include stabilization ponds, constructed wetlands, oxidation ditch, soil aquifer treatment.

Different crops and varieties for their tolerance to tannery effluent polluted soil and found Maize (Co. 1), finger millet (Co. 13), sugarcane (CoC 771), fodder grass (BN 2), Desmanthus and Korai grass tolerate the tannery effluent pollution to some extent higher yield [63].

Table 3. Tolerant crops in the industrial effluent area

\begin{tabular}{lll}
\hline \multicolumn{1}{c}{ Trees } & \multicolumn{1}{c}{ Shrubs } \\
\hline Acacia, Sweet (Acacia farnesiana) & Bahama Cassia (Cassia bahamiensis) \\
Black Olive (Bucida buceras) & Cocoplum (Chrysobalanus icaco) \\
Cassia (Cassia spp.) & Crown of Thorns (Euphorbia milii) \\
Oleander (Nerium oleander) & Dwarf Oleander (Nerium oleander) \\
Autograph Tree/Pitch Apple (Clusia rosa) & Eleagnus/Silverthorn (Eleagnus pungens) \\
Buttonwood (Conocarpus erectus) & Firecraker Plant (Russelia equisetiformis) \\
Gumbo Limbo (Bursera simaurubra) & Hibiscus (Hibiscus rosa-sinensis) \\
Orange Geiger Tree (Cordia sebestena) & Jamaican Caper (Capparis cynophallophora) \\
Paradise Tree (Simaruba glauca) & Jatropha (Jatropha hastata) & \\
Tropical Almond (Terminalia catappa) & Eucalyptus (Eucalyptus spp.) & \\
Thornless Acacia (Acacia choriophyll) & Ficus (all varieties) (Ficus spp.) & Field crops \\
\hline Fruit & Flowers & Barley (Hordeum vulgare) \\
\hline Loquat (Eriobotrya japonica) & Aster (Aster Ipinus) & Ragi(Co. 13) \\
Natal Plum (Carissa macrocarpa) & Marigold (Tagetes erecta) & corana) \\
Noni (Morinda citrifolia) & Chrysanthemums & Sunflower \\
Prickly Pear Cactus (Opuntia spp.) & (Chrysanthelianthus \\
Tamarind (Tamrindus indica) & Petunia (P. axillaris) & annuus) \\
Canistel/Eggfruit (Pouteria campechiana) & Phlox(Phlox longifolia) & Maize (Co. 1) (Zea mays) \\
Cashew Tree (Anacardium occidentale) & Celosia (Celosia cristata) & Sugarcane \\
Cattley/Strawberry Guava (Psidium cattleianum) & Petunia (P. axillaris) & (Saccharum officinarum) \\
Cherry of the Rio Grande (Eugenia aggregate) & Zinnia (Zinnia peruviana) & \\
Citrus (Citrus spp.) & & \\
Custard Apple (Annona reticulate) & & \\
Fig (Ficus carica) & & \\
Guava (Psidium guajava) & & \\
\hline
\end{tabular}




\section{CONCLUSION}

As the saying "Nothing is waste under god's creation", almost all the wastes generated can be reused after proper treatment. In the same way, the effluents and solid wastes let out from industries after undergoing primary and secondary treatments can be used to improve the productivity of the crops. But the seed production of food crops by using effluents should be avoided because accumulation of heavy metals in the seed and its transfer on further multiplication through food chain can cause increase in phototoxic concentrations and generates adverse effects not only on plants but also poses risks to human health. But with escalating situations of water scarcity industrial effluents could be well used for growing flower, ornamental and tree plantation. However, at diluted concentration of effluents also could be used for seed management technique, based on its growth stimulating property and based on the type of effluent either organic or inorganic.

\section{COMPETING INTERESTS}

Authors have declared that no competing interests exist.

\section{REFERENCES}

1. Avialable:Dpcc.delhigovt.nic.in

2. Srivastava RK. Effect of paper mill effluent on seed germination and early growth performance of radish and onion. $\mathrm{J}$. Ecotoxicol. Environ. Monit. 1991;1:1318.

3. Hari OM, Singh N, Aryo MS. Combined effect of waste of distillery and sugar mill on seed germination, seedling growth and biomass of okra (Abelmoschus esculentus (L.) Moech). Journal of Environmental Biology. 1994;15:171-175.

4. Hema S, Subramani T, Elango L. GIS study on vulnerability assessment of water quality in a part of Cauvery river. International Journal of Environmental Science, 2010;1:1-17.

5. Rehman A, Anjum MS. Cadmium uptake by yeast from industrial effluents and its potential use in wastewater clenup operations. Water, Air and Soil Pollution. 2010;205:149-159.

6. Shokoohi R, Saghi MH, Ghafari HR, Hadi M. Biosorption of iron from aqueous solution by dried biomass of activated sludge. Iran Journal of Environmental Health Science and Engineering. 2009;6(2):107-114.

7. Gowd SS, Reddy MRM, Govil PK. Assessment of heavy metal contamination in soil at Jajmau (Kanpur) and Unnao industrial areas of the Ganga plain, Uttar Pradesh, India. Journal of Hazardous materials. 2010;174:113-121.

8. Murugesan AG, Maheshwari S, Bagirath, G. Biosorption of cadmium by live and immobilized cells of Spirulina platensis. Journal of Environmental Resource. 2008;2(3):307-312.

9. Available:www.downtoearth.org.in

10. Available:www.cseindia.org

11. Ahmed WA, Zakaria ZA, Razali F, Samin J. Evaluation of combined chromium removal capacity of sawdust and immobilized Acinetobacter haemoluticus supplied with brown sugar. Water, Air and Soil Pollution. 2009;204:195-203.

12. Rajannan G, Devarajan L, Oblisami G. Impact of distillery effluent irrigation on growth of banana crop. Proceedings of National Seminar on Application of Treated Effluents for Irrigation, March 23, Triuchirapalli. 1998;56-59.

13. Behera BK, Misra BM. Analysis of the effect of industrial effluent on growth and development of rice seedlings. Environmental Research. 1982;28:1020.

14. Sahai R, Neelam S. Effect of fertilizer factory and distillery effluent on the seed germination, seedling growth and pigment content and bio-mass of Phaseolus radiatus L. Indian J. Ecol. 1987;14:21-25.

15. Dixit A, Laxman M, Srivastava SK. Effect of cardboard factory effluent of seed germination and early seedlings growth of rice seeds. Seed Res. 1986;14:66-71.

16. Kannan K, Oblisami G. Decolourisation of pulp and paper mill effluent by growth of Aspergillus niger. World J. Microbio. Biotechnol. 1990;6:114-116.

17. Gomathi V, Oblisami G. Effect of pulp and paper mill effluent on germination of tree crops. Indian J. Environ. Health. 1992;34:326-328.

18. Karunyal S, Renuga G, Paliwal K. Effects of tannery effluent on seed germination, leaf area, biomass and mineral content of some plants. Bioresour. Technol. 1994;47:215-218. 
19. Zalawadia NM, Raman S. Effect of distillery wastewater with graded fertilizer levels on sorghum yield and soil properties. J. Ind. Soc. Soil Sci. 1994;42:575-579.

20. Selvakumar S. Effect of tannery effluent on seed germination, seedling growth in neem. M.Sc Thesis, Dept. of Environmental Sciences, Tamil Nadu Agricultural Univeristy, Coimbatore; 1999.

21. Udayasoorian C, Mini K, Ramaswami PP. Case study on the utilization of paper and pulp mill effluent irrigation for field crops. In: Proc. Bioremediation of Polluted Habitats, Tamil Nadu Agric. Univ., Coimbatore. 1999;71-72.

22. Chinnusamy C, Annadurai K, Jayanthi C, Veeraputhiran R, Karunanthi S. Organic amendments and distillery effluent on soil fertility and productivity of rice. Proceedings of National Seminar on Use of Poor Quality Water and Sugar Industrial Effluents in Agriculture, Feb. 5, TNAU, Tiruchirapalli. 2001;84-84.

23. Sundaramoorthy $P$, Kunchithapatam J, Thamizhiniyan $P$, Venkateslu V. Effect of fertilizer factory effluent on germination and seedling growth of groundnut varieties. J. Ecobiol. 2001;13(1):03-08.

24. Ramana S, Biswas AK, Kundu S, Saha JK, Yadava RBR. Effect of distillery effluent on seed germination in some vegetable crops. Bioresour. Technol. 2002;82:273-275.

25. Aliotta G, Fiorentino A, Oliva A, Temussi F. Olive oil mill wastewater: Isolation of polyphenols and their phytotoxicity in vitro. Allelopathy J. 2002;9:9-17.

26. Sharma $V$, Sharma $R$, Sharma KD. Distillery effluent on seed germination, early seedling growth and pigment content of sugar beet (Beta vulgaris Linn. var. poly). J. Environ. Biol. 2002;23:77-80.

27. Vidhya S. Assessment of ecofriendly utilisation of distillery spentwash in dryland agriculture. M.Sc Thesis, Dept. of Environmental Sciences, Tamil Nadu Agricultural Univeristy, Coimbatore; 2003.

28. Vijayakumari B. Impact of textile dyeing effluent on growth of Soybean (Glycine $\max$ L.). Ecotoxicol. Environ. Monit. 2003;13:59-64.

29. Udayasoorian C, Jothimani P, Prabu PC. Impact of treated papermill effluent and organic amendments on bhendi. J. Environ. Res. 2003;13(2):50-56.
30. Kaushik P, Garg VK, Singh B. Effect of textile effluents on growth performance of wheat cultivars. Bioresour. Technol. 2005;96:1189-1193.

31. Singh PK, Sharma KP, Kumar S, Sharma $S$, Subhasini. Assessment of environmental contamination potential of distillery effluent using plant and animal bioassays. Nat. Environ. Poll. Technol. 2007;6:63-74.

32. Madhumita $P$, Joshi HC, Sairam RK. Germination behaviour and physiological response of rice to paper mill effluent application. Indian J. Plant Physiol. 2007;12(4):388-392.

33. Soundarrajan M, Pitchai GJ. Impact of distillery spentwash on seed germination, seedling growth and yield of Bhendi (Abelmoschus esculentus). J. Ecobiol. 2007;20:385-390.

34. Muthalagi S, Mala S. Impact of sewage on germination of Brassica nigra and Trigonella foenum. J. Ecotoxicol. Environ. Monit. 2007;17:55-60.

35. Yadav J, Meenakshi P. Impact of surgical effluent on germination, seedling growth and yield of selected crops. J. Ecotoxicol. Environ. Monit. 2007;17:151-158.

36. Pandey SN, Nautiyal BD, Sharma CP. Pollution level in distillery effluent and its phytotoxic effect on seed germination and early growth of maize and rice. Journal of Environmental Biology. 2008;29(2):267270.

37. Mahimairaja. Effect of spent wash on germination in maize, sunflower and red gram. Annual Report, Dept. of Environmental Sciences, Tamil Nadu Agricultural Univeristy, Coimbatore; 2008.

38. Kalaiselvi $P$, Shenbagavalli S, Mahimairaja $S$, Srimathi P. Impact of post biomethanated distillery spentwash on seed germination and seedling growth of dryland crops. Madras Agricultural Journal. 2009;96:331-334.

39. Baskaran L, Sundaramoorthy $P$, Chidambaram ALA, Sankar Ganesh K. Growth and physiological activity of green gram under stress. Botany Research International. 2009;2(2):107-114.

40. Dhanam S. Effect of dairy effluent on seed germination, seedling growth and biochemical parameter in paddy. Botany Research International. 2009;2(2):6163. 
41. Kailas MD, Ejazuddin Khan M, Joseph Rapolu, Asif Shaikh. Physicochemical analysis of sugar industry effluent and its effect on seed germination of Vigna angularis, Vigna cylindrical and Sorghum cernum. Annals of Environmental Science. 2011:5:7-11.

42. Rajaram N, Janardhanam K. Effect of distillery effluent on seed germination and early seedling growth of soybean, cowpea, rice and sorghum. Seed Res. 1988;16:173-177.

43. Rout GR. Studies on physic-toxicity of paper mill effluent on Phaseolus aureus. Andhra Pradesh Agri. J. 2008;37:24-28.

44. Mishra P, Bera AK. Effect of tannery effluent on seed germination and early seedling growth in wheat. Seed Res. 1995;23:129-131.

45. Rani R, Alikhan MA. Utilization of distillery effluent and its effect on growth and physiology of Oryza sativa L. Proceedongs of the National Conference on Ecofriendly Utilization of Recyclable Organic Resources from Sugar and Distillery Industries for Sustainable Agriculture, March 6-7, Trichy. 2007;1-9.

46. Natarajan K. Seed production, processing and storage techniques in petunia (Petunia grandiflora) cv. MIX. Ph.D Thesis, Dept. of Seed Science and Technology, Tamil Nadu Agricultural Univeristy, Coimbatore; 2003.

47. Goutam DD, Bishnoj S. Studies on the effluents of urmal dairy effluent dairy effluent on soil characteristics and growth of wheat plant. Adv. PI. Sci. 1990;3(2):26244.

48. Goutam DD, Kumar K, Bishno S. Effect of diary effluent on seed germination of some Rabi and Kharif crop plants. J. Environ. Biol. 1992;13(1):7-12.

49. Sharma NK, Goswami Bhakti, Gajjar Bijal, Jain Chirag, Soni Deepak, Patel Krishna. Utilization of amul dairy effluent for agriculture practices. International Journal of Environmental Sciences. 2011;2(1):2232.

50. Rani R, Shrivastava MM. Euphysiological response of Pisum sativum and Citrus maxima to distillery effluents. Inter. Eco. Environ. Sci. 1990;16:126-132.

51. Pandey DK, Soni P. Comparative study of germination of Acacia catechu and Moria alba seeds under effluent irrigation. Van Vigyan. 1994;32:29-36.

52. Mahimairaja S, Bolan NS. Problems and prospects of agricultural use of distillery spentwash in India. In: Proceedings of Supersoil 2004: $3^{\text {rd }}$ Australian New Zealand Soils Conference, Dec.5-9, University of Sydney, Australia; 2004.

53. Chandra R, Kumar P, Singh J. Impact of an aerobically treated and untreated (raw) distillery effluent irrigation on soil micro flora, growth, total chlorophyll and protein contents of Phaseolus aures L. J. Environ. Biol. 2004;25(4):381-385.

54. Garg VK, Kaushik P. Influence of textile mill waste water irrigation on the growth of sorghum cultivar. Applied Ecology and Environmental Research. 2007;6(2):112.

55. Kannan A, Upreti RK. Influence of distillery effluent on germination and growth of mung bean (Vigna radiata) seeds. J. Hazard. Mater. 2008;153(1-2):609615.

56. Rita, Jha PK, Belbase N. Effect of distillery effluent on some agricultural crops: A case study of environmental justice to local farmers in Khajura. Scientific World. 2008;6:68-75.

57. Indra $\mathrm{P}$, Ravi Mycin T. Germination changes of varieties of Vigna mungo L. under tannery effluent stress. Recent Research in Science and Technology. 2009;1(5):217-222.

58. Chidananda VC. Nutrient management with spent wash to augment productivity in groundnut (Arachis hypogaea L.) cv. TMV7. M.Sc Thesis, Dept. of Seed Science and Technology, Tamil Nadu Agricultural Univeristy, Coimbatore; 2010.

59. Kumar G, Sharmica Banu G, Kannan. Effects of textile mill effluents on seed germination, seedling growth and pigment content on Arachis hypogea. J. Ecobiol. 2006;19(1):19-22.

60. Saravanamoorthy MD, Ranjitha Kumari BD. Effect of textile waste water on morphophysiology and yield on two varieties of peanut (Arachis hypogaea L.). Journal of Agricultural Technology. 2007;3(2):335-343.

61. Giovacchino LD, Basti C, Costantini N, Ferrante ML, Surrichhio G. Effects of olive vegetable water spreading on soil 
cultivated with maize and grapevine. Agric. Med. 2001;131:33-41.

62. Food and Agricultural Organisation. Wastewater treatment; 2006.

Available:http://www.fao.org/docrep/t0551e /t0551e06
63. Singaram P. Effect of industrial and sewage effluents on soil and crop production. Agricutlural Inputs and Environment. (Ed.) Sp. Palaniappan Scientific Publishers. Jodhpur. 1995;357388.

(C) 2019 Venudevan et al.; This is an Open Access article distributed under the terms of the Creative Commons Attribution License (http://creativecommons.org/licenses/by/4.0), which permits unrestricted use, distribution, and reproduction in any medium, provided the original work is properly cited.

Peer-review history:

The peer review history for this paper can be accessed here: http://www.sdiarticle3.com/review-history/11427 